\title{
The potential of temporary migration programmes in future international migration policy
}

A paper prepared for the Policy Analysis and Research Programme of the Global Commission on International Migration

\author{
by \\ Martin Ruhs \\ Centre on Migration, Policy and Society (COMPAS) \\ University of Oxford
}

martin.ruhs@compas.ox.ac.uk

September 2005

The analysis provided in this paper is that of the author, and does not represent the views of the Global Commission on International Migration. 


\section{Introduction $^{1}$}

A number of high-income countries have recently considered the (re-) introduction, or expansion, of temporary migration programmes (TMPs) as one of the possible policy tools to manage labour immigration. For example, the United States is currently considering the introduction of a new large scale guest-worker-programme for Mexican workers. The UK is already experimenting with a new pilot scheme for the temporary employment of migrant workers in selected low-skill occupations in hospitality and food processing. Italy and Spain - two recent countries of immigration - are also actively pursuing TMPs, most of them within the framework of bilateral agreements with sending countries in Northern Africa and Latin America.

Given their adverse history in liberal democracies, the re-emergence of TMPs is highly contested in both the academic and policy community. Critics argue that such programmes are both unfeasible and undesirable in a liberal democracy. This argument is primarily based on the fact that many of the past guest worker programmes - most notably the Bracero programme in the United States (1942-64) and the Gastarbeiter programme in Germany (1955-73) - failed to meet their stated policy objectives and instead generated a number of unanticipated consequences. This included the non-return and eventual settlement of many guest workers. The slogan "there is nothing more permanent than temporary foreign workers" has been a popular summary statement of the perceived failure of past guest worker programmes. ${ }^{2}$

Discussions and proposals of new and improved TMPs do not dispute the adverse consequences of such programmes in the past. Proponents of new TMPs argue that innovative policy designs could help avoid the past policy mistakes and generate significant benefits for all sides involved, including migrant workers and their countries of origin. ${ }^{3}$

This paper discusses the potential of TMPs in future international migration policy. Following a definition and brief typology of TMPs, the paper discusses whether and how such programmes can (a) help high-income countries to meet their labour market needs; (b) provide people from low-income countries better access to labour markets in higherincome states; (c) maximize the developmental impact of migration in countries of origin; and (d) address concerns in high-income countries about the permanent settlement of migrants and the diversity of their societies. ${ }^{4}$ The discussion draws upon the outcomes

\footnotetext{
${ }^{1}$ For their helpful comments, I would like to thank Manolo Abella, Bridget Anderson, Jorgen Carling, Jeff Crisp, Lindsay Lowell, Emma Newcombe, Sarah Spencer and Nick Van Hear.

${ }^{2}$ There is a plethora of studies providing empirical evidence for the "policy failures" of past guest worker programmes. For overviews, see, for example, Castles (1986) and Martin and Teitelbaum (2001).

${ }^{3}$ For discussions of the need and policies for new and improved TMPs, see, for example, Schiff (2004), Martin (2003), and Ruhs (2003).

${ }^{4}$ The distinction between low-income, migrant sending countries and high-income, migrant-receiving countries is a convenient shorthand/simplification. Of course, it is important to recognize that there is significant migration to middle-income countries, and also between low-income countries. In 2000, it was estimated that 37 per cent of the world's international migrants live in developing countries (IOM 2005).
} 
and policy experiences of different TMPs. It identifies the core considerations and policies needed to formulate and effectively implement TMPs.

\section{Definition}

Discussions of TMPs frequently suffer from a confusion in the underlying definition of such programmes. For example, critics sometimes seem to assume that, by definition, migrant workers admitted and employed under TMPs can never acquire permanent residence. At the same time, some proponents of temporary migration schemes appear to take for granted that migrants naturally acquire rights over time and that employment as a temporary worker is simply a first step toward permanent residence. Both of these assumptions are unhelpful as they introduce an immediate bias to how TMPs are evaluated.

This paper will work with a simple but strict definition of a TMP that, in principle, could provide the basis of a wide range of temporary migration policies. For the purpose of this paper, the key feature of a TMP is that residence and employment on the basis of a temporary work permit alone does not create an entitlement to stay permanently in the host country. This definition obviously implies that migrants whose temporary work permits have expired, and who have not been accorded permanent immigrant status (see below), lose their right to residence in the host country and are thus expected to return home or migrate elsewhere.

At the same time, it is important to emphasise that the definition above does not exclude the possibility that some migrants admitted under TMPs are eventually granted permanent residence in the host country. Rather than becoming a right that migrants can acquire by virtue of their residence and employment on temporary work permits alone, however, it is implied that the granting of permanent residence for migrants on temporary work permits remains at the discretion of the host state.

In principle, there is a wide spectrum of criteria that host states could use to decide whether to grant migrants employed on temporary work permits permanent immigrant status or not. Furthermore, these criteria may vary over time and across countries. For example, if the economic circumstances are right, a host country may decide, on purely economic grounds, to grant permanent residence to some or most migrants who manage to have their temporary work permits renewed for a certain number of years. ${ }^{5}$ Host countries may also grant temporary migrants permanent residence based on noneconomic grounds, such as marriage to a citizen or a permanent resident. A third and more extreme policy position would be to never grant permanent residence to any - or a certain category of - migrant workers admitted on temporary permits. ${ }^{6}$

\footnotetext{
${ }^{5}$ For example, under the UK's main work permit programme for skilled migrant workers, migrants employed on temporary work permits may apply for "indefinite leave to remain" (i.e. permanent residence) after 4 years of employment in the UK.

${ }^{6}$ The current work permit policies in many of the Gulf Cooperation Council (GCC) states and in Singapore are cases in point. For example, in Kuwait there is effectively no possibility for migrants employed on
} 
Despite the different approaches to the issue of permanent residence for migrants employed on temporary work permits, the combining feature of these examples is that permanent residence is granted by the host country as a matter of discretion, i.e. based on certain reasons and criteria, rather than acquired by a migrant worker on the basis of a specified period of residence in the host country alone.

\section{Typology}

TMPs may take on a variety of forms and policy structures. Broadly speaking, TMPs may differ with regard to: (i) the mechanisms for admitting migrants including the existence of bilateral recruitment agreements with sending countries; (ii) the policies for selecting migrants including the required skill level of migrants eligible, and migrants' sector of employment in the host country; (iii) the rights granted to migrants after admission including the duration of, and conditions attached to, the work permits issued; and (iv) the primary policy objectives.

Mechanisms for regulating admissions One may broadly distinguish between three modes of regulating the number of (annual) admissions under a TMP: quotas; economically oriented work permit fees; and laissez-faire admissions. For example, in the United States, Congress sets an annual quota for the number of skilled and specialized migrants admitted under the H-1B programme. ${ }^{7}$ Annual quotas are also used in Austria where they apply to both employment and residence policy. ${ }^{8}$ In contrast, Singapore uses economically oriented fees to manage the size of temporary labour immigration. Singapore's "foreign worker levies" - payable by the employer for each migrant worker employed - are specific to the sector of employment and the skill level of the migrant worker. ${ }^{9}$ Finally, before EU enlargement, Ireland's temporary work permit system was a good example of a TMP based on laissez-faire admissions, under which the annual number of permits issued is simply determined by employers' demand for migrant workers. ${ }^{10}$ Each of these admission policies may or may not be accompanied by some sort of 'labour market test' that aims to ensure that migrant workers are only admitted after employers have seriously and unsuccessfully searched for local workers to fill the existing vacancies.

Bilateral agreements TMPs may be open to admitting nationals of any country or operate on the basis of bilateral recruitment agreements or MOUs. ${ }^{11}$ Examples of the latter

\footnotetext{
temporary work permits to acquire permanent residence. In Singapore, the same applies for migrants employed on temporary permits for employment in low-skill jobs.

7 The quota for 2004 was 65,000, excluding dependents who are allowed to join the H1-B visa holder in the US.

${ }^{8}$ See the discussion in Cholewinski (2005).

${ }^{9}$ See the website of the Singaporean Ministry of Manpower at www.mom.gov.sg

${ }^{10}$ Given Ireland's booming economy, the number of work permits for non-EEA nationals increased from less than 6,000 in 1999 to almost 48,000 in 2003, before declining - because of EU enlargement - to 34,000 in 2004. See Ruhs (2005a).

${ }^{11}$ There has recently been a significant increase in the number of bilateral recruitment agreements in OECD countries. See the recent review by the OECD (2004).
} 
include: the Bracero programme in the US (for Mexican farmworkers, 1942-64); the Gastarbeiter programme in Germany (bilateral recruitment agreements with eight different countries ${ }^{12}, 1955-73$ ); and some of the recent TMPs in Spain (including bilateral agreements with Columbia, Ecuador and the Dominican Republic since 2001), and in Germany (e.g. MOU with Poland, facilitating a contract worker scheme since 1996).

Required skill level TMPs may also specify the skill level required for migrants to join the programme. In fact, most countries that use TMPs to manage labour immigration operate different programmes for skilled and low-skilled migrants. Examples include: the US (the H1-B programme for workers in specialty occupations; the H2-A/B programmes for low-skilled foreign workers); the UK (the main work permit scheme for skilled workers; and a number of sector based programmes for the employment of migrants in low-skill jobs); and Singapore ('employment passes' are issued to highly skilled workers with wages above a certain level; 'work permits' are issued to workers with wages below a certain level).

Sector of employment In order to fill sector-specific labour shortages, TMPs may admit migrants for employment in specified sectors only. For example, most seasonal programmes, such as seasonal agricultural worker schemes, are sector specific. The UK has recently introduced a new Sector Based Scheme (SBS) for the temporary employment of migrant workers in low-skill occupations in the food manufacturing and hospitality sectors. ${ }^{13}$ Ireland issues work visas/authorizations for skilled migrants to be employed in a list of 'shortage occupations'.

Duration of the work permit. The majority of past and existing TMPs have issued work permits that are valid for a period ranging between a minimum of 3 months and a maximum of 5 years. Permits that are valid for less than a year are usually only issued by seasonal programmes that aim to use migrant workers to fill strictly temporary (including seasonal) labour shortages. Examples include the Canadian Seasonal Agricultural Worker Programme (CSAWP) and the UK's Seasonal Agricultural Workers Scheme (SAWS). Most of the traditional 'guest worker programmes' issued permits that were valid for at least one year. In most, but not all, cases such work permits were renewable, either for the same time that the initial permit was valid for, or for a longer period (as was the case under the German Gastarbeiter programme ${ }^{14}$ ). Some, but again not all, TMPs have put a limit on the number of times that a temporary work permit can be renewed ${ }^{15}$.

\footnotetext{
${ }^{12}$ Germany struck bilateral recruitment agreements with Italy (1955), Spain and Greece (1960), Turkey (1961 and 1964), Morocco (1963), Portugal (1964), Tunisia (1965) and Yugoslavia (1968).

${ }^{13}$ In June 2005, the sector based scheme was closed for the hospitality sector. This was because of alleged abuses of the system (see UK Home Office 2005b) and the availability of workers from the new EU member countries who have been able to work in the UK without work permits since EU enlargement on $1^{\text {st }}$ May 2004. The government expects employers in the hospitality sector to meet all of their demand for low skilled workers from within the enlarged EU.

${ }^{14}$ The German Gastarbeiter programme initially issued work permits that were valid for one year and renewable. After residence of three years, two or more year work permits could be issued.

${ }^{15}$ For example, the Swiss Auslaenderausweis B programme issues work permits that are valid for one year and renewable for an unlimited number of times. In contrast, temporary work permits for low-skill migrants in Singapore are valid for two years and are renewable only once. Similarly, in the US, H1-B permits for skilled workers are issued for three years and renewable only once for another three years.
} 
Conditions attached to the work permit Almost all TMPs require migrant workers to work for the employer specified on the work permit only. ${ }^{16}$ Other restrictions of migrants' rights, including especially the right to family reunion and access to public services, vary between countries and programmes. ${ }^{17}$ For example, Ireland grants temporary migrants the right to family reunion, but only if they can support their immigrating dependents without recourse to public funds. In the UK, a similar rule applies to skilled migrants but migrants employed on temporary SBS permits (for employment in low-skill jobs in hospitality and the food processing sector) cannot apply to bring dependents to the UK. In both the UK and Ireland, migrants' access to public services and benefits, including unemployment benefits, is regulated by the 'habitual residency test', which means that migrants become eligible for certain benefits only after they have been in the country for a certain minimum period of time. For another example of restrictions of temporary migrants' rights, in Singapore, low-skilled migrants employed on work permits do not have the right to marry, or cohabit with, a Singaporean or permanent resident. Obviously, no such rules apply to migrants in liberal democracies.

Policy objectives Not all TMPs are exclusively driven by the goal of alleviating labour shortages in the host country. Other policy objectives have included: the reduction of illegal immigration (a major policy objective of many bilateral recruitment agreements struck by Italy and Spain); the promotion of special post-colonial or political relationships and of cultural ties and exchanges (e.g. the 'Working Holidaymaker' schemes in the UK, Australia, New Zealand and Ireland); and the training of migrants (e.g. the 'Trainee schemes' in Switzerland).

Of course, it needs to be added that overt objectives of a TMP do not always correspond with the actual policy objectives in practice. For example, some countries have effectively used the Working Holidaymakers scheme and the Trainee scheme for the primary purpose of filling labour shortages. For example, it is well known that the Trainee schemes in Japan and Korea have been primarily used to fill labour shortages rather than to provide training for migrants. For another example, Australia has recently announced that it would significantly increase admissions under its Working Holiday maker programme to help with seasonal harvest work.

The brief overview of the various dimensions of TMPs above makes clear that there is significant room for policy variation in such programmes. Of course, the optimal decisions on the various policy parameters will always critically depend on countryspecific institutional settings and economic circumstances. Rather than engaging in a detailed discussion of the advantages and disadvantages of the large number of different types of TMPs, this paper will focus on an evaluation of TMPs as defined above in the most general terms.

\footnotetext{
${ }^{16}$ Exceptions include mainly TMPs for highly skilled workers. For example, under the UK's Highly Skilled Migrant Programme (HSMP), migrants are admitted to the UK without having a prior job offer. Once they have found a job, they may freely change employers.

${ }^{17}$ For a recent overview of the legal status and rights of migrants admitted for employment in selected European countries, see Cholewinski (2005).
} 


\section{Helping high-income countries to meet their labour market needs}

Most high-income countries of immigration now recognize the need for migrant labour at both the high and low skill end of the labour market. The well known examples of highskill occupations requiring migrant workers include occupations in the health sector, IT, and finance. In many countries, migrants are also already filling vacancies in low-skill jobs in the hospitality sector, construction, cleaning, agriculture and food processing. The primary question is thus not any longer whether there is a need or, as economists prefer to call it, demand for migrant labour, but rather how big this demand is, and what policies are needed to meet it.

To answer the first question, it is necessary to recognize that, regardless of the economic conditions and the number of vacancies advertised in the economy, there is always a need for host countries to manage the demand for migrant labour. This is because the level of labour immigration that is in the interest of individual employers is unlikely to always coincide with that in the best interest of the overall economy. More specifically, any assessment of the size of the required migrant workforce needs to take account of three considerations.

First, individual employers' demand for labour critically depends on the cost at which workers can be recruited and employed. Importantly, the cost of employing migrant workers is not only determined by employers' recruitment and wage costs but also by the employment conditions at which migrant labour is available. If, for example, employers are in a position to lower costs by offering wages and employment conditions that are below minimum standards, the demand for migrants is likely to be higher than what it would be if employment laws were enforced. There is thus a need to make sure that the demand for migrant workers identified by employers is in fact a demand for workers who can be - and end up being - employed in compliance with existing employment laws and regulations.

Second, unless a decision has been taken to grant migrant workers from certain countries the right to employment in the host country without any restrictions ${ }^{18}$, it is generally accepted that local workers should enjoy a right to preferential access to the national labour market. ${ }^{19}$ This means that any demand for migrant labour must be a residual demand, that is, the demand for labour that remains after employers have made all reasonable efforts to recruit local workers. Any assessment of the demand for migrant workers must thus ascertain that employers have indeed made such efforts and that no local workers are available to fill the advertised vacancies.

\footnotetext{
${ }^{18}$ Recent examples of such a decision include the decisions of the UK and Ireland to grant migrants from the ten new EU member states free access to the Irish and British labour markets.

${ }^{19}$ The definition of 'local workers' varies across countries. A narrow definition includes citizens only. Broader definitions could include all permanent residents or even all nationals of a certain group of countries. For example, in any country of the EU, all nationals from within the EEA - the EU plus Norway, Iceland and Liechtenstein - enjoy an equal right to preferential access to the labour market vis-à-vis "thirdcountry" nationals.
} 
A third important reason for the need to manage the demand for migrant labour is that the employment of migrant workers is often only one of various possible ways in which employers may respond to perceived shortages of labour. The whole set of potential responses includes: (i) increasing the capital or technology-intensity of the production process (e.g. 'mechanization'); (ii) relocating to countries where labour costs are lower ('offshoring'); (iii) increasing working hours of already employed workers or try to recruit inactive or unemployed local workers (which may require raising wages and/or improving working conditions); (iv) switching output to less labour-intensive commodities or services; and/or (v) recruiting migrant workers. Although not all of these options are available to all employers at all times (e.g. it will clearly be impossible to offshore the work of waiters in hotels and restaurants), it is likely that many employers have at least some alternatives to the employment of migrant labour.

An employer's decision on how to respond to a perceived labour shortage will naturally depend on the relative cost of each of the available options. If the costs of employing migrant workers are very low, employers will not consider the alternatives. It could, for example, be argued that the ready supply of cheap labour may discourage some employers from modernizing production processes, and thus potentially lead to a situation where inefficient companies and industries remain viable only because they are subsidized by a readily available and cheap immigrant workforce. ${ }^{20}$ This may be in the short-term interest of individual employers but maybe not in the long-term interest of the host country's economy overall. There is thus a clear need to regulate the relative cost at which migrant workers are made available to local employers. This would help create the right incentive structures for employers in their decisions on how to best respond to perceived labour shortages. Viewed from this perspective, immigration can and needs to be considered as a tool of both labour market policy and industrial policy.

Many of the past and existing TMPs have not been successful at helping immigration countries to manage their demand for migrant workers in the ways described above. For example, temporary programmes have frequently failed in protecting the employment conditions of migrants. They have also often led to the emergence of labour market distortions and the growth of a structural dependence by certain industries on the continued employment of migrant workers. The latter has occurred due to labour market segmentations that arise as a result of the emergence of 'immigrant' sectors or occupations, i.e. types of work - often hard and low-paid - that become dominated by migrant labour and eventually shunned by local workers. ${ }^{21}$

It is thus clear that any efforts to use TMPs to effectively manage some of the demand for migrant labour need to learn from past policy mistakes. More specifically, at least three policies are necessary: (i) a strong policy commitment to enforcing immigration and employment laws, especially against employers; (ii) the active regulation of the cost at which migrant workers are made available to employers; and (iii) more effective

\footnotetext{
${ }^{20}$ Recent research by Lewis $(2005,2004)$ shows that the growth in less-skilled labour supply has slowed the adoption of automation technology in selected plants in US manufacturing. For another example, see Martin and Olmstead's (1985) discussion of the mechanization controversy in US agriculture.

${ }^{21}$ See the discussion of adverse consequences of five major guestworker programmes in Ruhs (2003).
} 
mechanisms for encouraging employers to search for local workers before demanding migrant labour.

\section{Enforcing immigration and employment laws}

The success of any TMP - or of any labour immigration policy more generally critically depends on the host country's willingness and capacity to strictly enforce the law against all parties - recruitment agents, employers and migrant workers - who illegally circumvent the programme. In the absence of effective law enforcement, employers and migrant workers may have very few incentives to join the TMP and prefer (the continuation of) illegal employment arrangements instead. ${ }^{22}$

Liberal and democratic host countries have a particularly poor record of enforcing the law against employers who illegally employ migrant workers. For example, in 2002, only 53 employers were fined for immigration violations in the whole of the US. ${ }^{23}$ Similarly, between 1998-2002, only 8 employers were found guilty of illegally employing migrant workers under Section 8 of the UK's Asylum and Immigration Act 1996, the law preventing illegal working in the UK. ${ }^{24}$ In Ireland - a recent country of immigration only three employers have so far been convicted of violating the Employment Permits Act $2003 .^{25}$

The failure to enforce employer sanctions is widely agreed to be one of the most important factors leading to illegal immigration and illegal working and, as a potential consequence, to the failure of labour immigration policies. This is because, in contrast to all other immigration control policies, employer sanctions serve the important purpose of addressing the demand for illegally employing migrant workers. Without policies that minimize demand, policies aimed at minimizing supply (border control, deportations) are likely to be much less effective than they could be.

Clearly, to facilitate increased and more effective enforcement of employer sanctions, two conditions need to be met. First, the effective implementation of employer sanctions needs to be feasible. Feasibility can be jeopardized by the spread of false documents, the rise of subcontractors and other middlemen who often help evade enforcement, insufficient enforcement budgets and insufficient co-operation between agencies. ${ }^{26}$ Maybe most importantly, employers need to be put in a position where they are able and may be reasonably expected - to quickly and correctly ascertain whether a migrant has the right to work in the host country or not. Among other things, this requires policymakers to provide employers with a clear list of documents that workers may

\footnotetext{
${ }^{22}$ This has been one of the main criticisms voiced again President Bush's proposal of introducing a new guest worker programme-cum-amnesty for Mexican workers seeking employment - or already employed in the US. The argument is that the policy will be ineffective unless illegal immigration is brought under better control.

${ }^{23}$ Cornelius (2004).

${ }^{24}$ UK Home Office (2003).

${ }^{25}$ Ruhs (2005a).

${ }^{26}$ See Martin and Miller (2000).
} 
provide to prove their right to work. It is also necessary to clarify the identity of the employer who can be held responsible for the violation of immigration and employment laws. This is particularly important in sectors where employment relations are characterized by potentially long chains of subcontracting such as in cleaning, construction and parts of agriculture.

A second obvious requirement for effective enforcement of employer sanctions is a strong commitment and political will on part of the host country's government to enforce the law against employers. There are signs in some countries that the commitment to enforcement is increasing ${ }^{27}$ but it clearly cannot be taken for granted. If employers demand migrant workers in numbers that are politically difficult or impossible to support, governments may be tempted to provide the demanded workers through 'benign indifference' to illegal immigration rather than through expanding legal labour immigration. A frequently cited example of such benign neglect over the issue of illegal immigration is US policy towards undocumented workers in agriculture, where internal and border enforcement efforts have been systematically relaxed during periods of high labour demand. ${ }^{28}$

\section{Regulating the cost of migrant labour}

In order to create the right incentive structure for employers, TMPs could charge employers a monthly fee for each migrant worker employed under the programme. The fee would need to be set at a level high enough to provide local employers with sufficient incentives a) to search for local workers who can be employed without paying the fee (this would effectively help protect local workers' right to preferential access to the labour market) and b) to consider alternative measures such as mechanisation or offshoring before considering the recruitment of migrant workers. If deemed necessary for industrial policy reasons, fees could be set at prohibitively high levels in industries considered to have lost comparative advantage to other, low-income countries. ${ }^{29}$ The revenues from work permit fees could also be used to generate funds for enforcement and integration assistance. ${ }^{30}$

While most of the existing and past TMPs have imposed administrative permit fees of some sort, Singapore has been among the very few countries to use economically oriented fees to "micromanage" the inflow and employment of temporary migrant

\footnotetext{
${ }^{27}$ For example, the recent consultation document on reforming the UK's immigration policies ('Making Migration Work for Britain") suggests a more determined approach to enforcing employer sanctions than has so far been the case. Among other things, the government says it intends to "develop closer joint working between departments responsible for enforcing workplace regulations. Departments are working together to develop a joint workplace enforcement team which will explore the scope for closer coordinated working between Government workplace enforcement departments to tackle both the use and exploitation of illegal migrant workers" (UK Home Office 2005a, p. 30).

${ }^{28}$ Hanson and Spilimbergo (2001)

${ }^{29}$ For most high income countries, labour-intensive manufacturing and, more controversially, parts of agriculture may be cases in point.

${ }^{30}$ Martin (2003).
} 
workers. According to Singapore's Ministry of Manpower, "the foreign worker levy is essentially a pricing tool to bridge the wage differentials between foreign workers and local employees. It is primarily used to moderate the demand for foreign workers". ${ }^{31}$ For example, the current monthly levy for employing a skilled migrant in Singapore's construction sector is $\mathbf{S} \$ 80$; the corresponding levy for employing an unskilled construction worker from abroad is $\mathrm{S} \$ 470 .^{32}$

To implement fees effectively, two main challenges need to be overcome. First, the government of the receiving country needs to accept the proposition that the merits of micro-managing the employment of migrant workers by setting employer fees justifies and outweigh the costs associated with increased government intervention. This may be a difficult step for governments with a strong preference for laissez-fairism and minimal government intervention in the domestic economy. Second, there is a danger that some employers will illegally deduct work permit fees from migrant workers' wages. If this happens, the fees will achieve none of their intended objectives and simply serve to reduce the wages of migrant workers. To prevent this, work permit fees need to be effectively enforced with credible and significant penalties for employers who pass the fees on to their workers, or who illegally employ migrants to avoid paying the fee altogether.

\section{Implementing effective labour market tests}

Labour market tests - i.e. mechanisms that ensure that local employers recruit migrant labour only after having made all reasonable efforts to recruit local workers - have shown to be notoriously difficult to implement in practice. Whenever necessary, employers have shown considerable ingenuity to ensure that no local workers are found to fill their vacancies. ${ }^{33}$ A worst-case scenario is one where both employers and local workers are actually not interested in engaging in an employment relationship. This could happen where employers have a pre-determined preference for employing migrant workers, and where local workers prefer to live off unemployment benefits rather than accept lowwage jobs.

Clearly, without the right incentives and enforcement, any labour market test simply becomes a bureaucratic obstacle that serves neither employers nor local workers. Importantly, the failure of the labour market test also leads so a situation where the number of migrant workers admitted is no longer aligned with the actual economic demand for migrant labour.

One potentially effective way of maximizing the probability of success of a labour market test is to require employers to advertise vacancies at a wage set by the government. In order to protect the job opportunities and employment conditions of local workers, this

\footnotetext{
${ }^{31}$ Taken from the website of the Singaporean Ministry of Manpower at www.mom.gov.sg

${ }^{32}$ In the first quarter of 2005 , the average monthly wage in Singapore's construction sector was $\mathbf{\$} \$ 2,680$. See www.singstat.gov.sg

${ }^{33}$ See Martin (2003).
} 
wage should equal or exceed the average wage (and working conditions) prevailing in that occupation and industry. A complementary measure aimed at ensuring that the recruitment of migrant workers does not adversely affect local workers is the requirement that no local workers are laid off during a set period before and after the employment of a migrant.

Of course, any policy to test the labour market before issuing work permits will only be effective if it is enforced. In particular, there is a need for post-hoc enforcement that monitors whether or not employers meet their obligations. The US 'labour certification system $^{34}$ is an example of a system where the lack of enforcement has been a major factor in enabling some employers to essentially bypass the labour market test. As a result, migrant workers are sometimes recruited even when it is not clear that there is a shortage of local workers. ${ }^{35}$

The implementation of a two-tier system may also help improve the outcomes of a labour market test: in sectors or occupations which are verifiably known to suffer from shortages of local workers, some of the components of a labour market test (such as the requirement to actively search for local workers) could be waived ${ }^{36}$; the remaining sectors/occupations would still be subject to a labour market test which could be more focused and therefore potentially more effective. Other possibilities for testing the labour market and, more generally, assessing employer demand for migrant labour include auctions ${ }^{37}$ and other market-based tradeable permit systems. ${ }^{38}$ Of course, these are just suggestions rather than tried-and-tested solutions. There is a need to experiment with innovative policies that might be more effective than most current policies in gauging employer demand for migrant labour.

The basic conclusion to be drawn from the discussion so far is this: whether TMPs can help host countries to effectively manage the demand for migrant labour critically depends on whether it will be possible to design and implement innovative policies that avoid past policy mistakes. This will require experimentation, resources and, most importantly, recognition that, to be effective in meeting some of the labour market needs of host countries, TMPs will always require a significant degree of government involvement. It is unlikely that there will ever be a successful TMP with only minimal government intervention.

\footnotetext{
${ }^{34}$ Employers in the United States who wish to apply for an H-1B work permit need to attest, among other things, that they will pay the migrant worker the higher of the actual wage paid to other workers similarly employed or the prevailing wage for the occupation in the vicinity; and that the employer will provide working conditions for H1-B workers that will not adversely affect the working conditions of similarly situated US workers. Until recently, "H-1B dependent" employer (i.e. firms with more than a certain share of the workforce who are H-1Bs) needed to further attest that: no US workers are laid off for the three months before and the three months after hiring of the H-1B; and that significant efforts have been made to recruit US workers. See http://workforcesecurity.doleta.gov/foreign/hiring.asp

${ }^{35}$ See the discussion in Lowell (2005).

${ }^{36}$ This is already done in some countries including the UK where certain shortage occupations are exempted from the labour market test. See www.workingintheuk.gov.uk .

${ }^{37}$ See, for example, DeVoretz (2002).

${ }^{38}$ See, for example, Weinstein (2002).
} 
It is also important to recognise that TMPs alone are unlikely to suffice as a way of managing the employment of migrant workers to meet the labour market needs in high income countries. For example, because of significant international competition for highly skilled and specialized migrant workers such as doctors and IT specialists, the restrictions of stay and employment necessarily associated with TMPs may not be suitable for recruiting highly skilled workers. This has recently been illustrated by the failure of Germany's 'Green Card' programme - which offered a strictly time-limited 5 year work permit - to attract significant numbers of highly skilled migrants. It is likely that the effective recruitment of 'foreign talent' requires the offer of permanent residence immediately - or at least very soon after - arrival.

\section{Providing workers in low-income countries better access to labour markets in higher-income countries}

Today's international economic integration is primarily driven by international trade and capital flows, with foreign workers playing only a relatively minor role in the global economy. As of 2000, the ratios of exports and the stock of outward foreign direct investment to world GDP were 22.1 per cent and 18.7 per cent, respectively ${ }^{39}$, while the ratio of the estimated stock of total migrants to total world population was only about 3 per cent (based on an estimated global stock of 175 million migrants, the great majority of whom are migrant workers). ${ }^{40}$ This asymmetry in the globalization process is, of course, largely a result of the fact that most high income countries have pushed for the liberalization of international trade and capital flows, while at the same time maintaining restrictions on labour immigration flows. As another reflection of this differential policy approach, the governance and liberalization of international labour flows has - so far not been given the kind of international institutional support that has been in place for liberalizing international capital and trade flows (through, for example, the World Trade Organisation).

In most high income countries, labour immigration policies toward low-skilled migrant workers are currently significantly more restrictive than those toward skilled and highlyskilled migrants. ${ }^{41}$ This currently holds true for most traditional immigration countries such as the US, Canada and Australia - as well as, at least until recently, the UK and most of the European countries that carried out guest worker programmes for workers of

\footnotetext{
${ }^{39}$ In 2000, the ratio of FDI outward-flows to total fixed capital accumulation was 17.8 percent (UNCTAD, 2001). Of course, FDI figures are not strictly comparable to figures of GDP and fixed capital accumulation. The idea here is to merely give an indication of the overall magnitudes under consideration, rather than identify the exact degree of the integration of international capital markets.

${ }^{40}$ See UNPD (2002).

${ }^{41}$ Note the emphasis on labour immigration policies. Of course, many countries' family-based immigration and asylum policies do result in the inflow of significant numbers of migrants with a relatively low level of skills. In many countries, including the US and Canada, labour immigration policies constitute only a small share of overall immigration policies.
} 
all skill levels in the 1960s and 1970s. ${ }^{42}$ Notable exceptions include Singapore and the resource-rich countries in the Persian Gulf. Both countries are using TMPs to admit and employ relatively large numbers of migrants for employment in low-skilled occupations.

Of course, given the demand in high income countries for migrant labour at both the high and low skill end of the labour market, restrictions on low-skill immigration have not prevented large numbers of workers from low-income countries, and employers in higher-income countries, from circumventing the law and entering into illegal employment arrangements. For example, both the US and the UK - two countries that have in recent years been relatively restrictive with regard to the legal immigration and employment of low-skilled migrant workers - are known to host significant numbers of migrants working illegally in low-wage jobs. ${ }^{43}$

The introduction or expansion of TMPs could significantly increase the (legal) access of workers in low-income countries to labour markets in many high income countries, especially at the low skill end of the labour market where the opportunities for legal employment are currently most limited. However, to do so in a manner that increases the overall benefits for migrants, it is necessary to implement measures that: (i) ensure that migration costs (e.g. travel and recruitment costs) that migrants incur under a TMP are lower than those incurred when migrating illegally; and (ii) minimize the danger that improved access to labour markets in high-income countries leads to pressure on migrants' employment conditions and exploitation while employed abroad.

\section{Controlling migrants' costs of migration}

To facilitate better access to labour markets in high income countries, a TMP needs to make sure that the migration costs of the migrants joining the programme are actually lower than those incurred by workers migrating and finding jobs illegally. This will only be achieved if the payments that migrants usually make to people smugglers in order to illegally cross borders are not replaced by payments that need to be made to unscrupulous employers selling work permits to migrants. Although there is no evidence on the level of incidence, the sale of visas and work permits is known to have been a problem under a variety of TMPs in different countries. The enforcement measures required to avoid the sale of visas will need to include strict enforcement against employers who sell visas and an effective regulation of the private migrant recruitment industry that exists in both receiving and sending countries of migrant labour.

\footnotetext{
${ }^{42}$ Because of EU enlargement, the member states of the pre-enlarged EU (EU15) are about to become - or have already become - significantly more open to the immigration and employment of low-skilled workers from the ten new EU member states. The UK, Ireland and Sweden have already opened up their labour markets to accession state nationals who now no longer require work permits to legally take up employment in those three countries; the remaining EU 15 countries are required to do the same within six years.

${ }^{43}$ Of course, this is not to say that illegal immigration and/or illegal working only occurs in countries that do not offer sizable labour immigration programmes for low-skilled workers. The question of whether and how legal immigration opportunities affect illegal immigration remains contested.
} 


\section{Safeguarding migrants' rights}

The overall interest of migrants includes both their economic welfare, i.e. their wages and employment prospects, and migrants' rights. It is important to recognize that any TMP necessarily involves at least some trade-off between the economic gains that the access to labour markets in high income countries is usually associated with, and restrictions of some of the individual rights of migrants while employed abroad. For example, to align labour immigration with the economic needs of the host country, migrants admitted under a TMP will need to be required to work within a specified sector of the host country's labour market only (see the discussion below). This requirement obviously restricts a migrant's right to freedom of movement in the host country's labour market, a right enjoyed by most people in their home countries.

It is important to realize that workers in low-income countries - especially those with little or no other opportunities to economically better themselves and their families - are likely to accept at least some restrictions of their rights in return for improved access to labour markets in high income countries. In fact, given the large income inequalities between high and low income countries, migrant workers may sometimes be willing to trade economic gains for restrictions in personal rights to an extent that is likely to be considered unacceptable in most liberal democracies. Two extreme examples are migrant workers from developing countries, who choose to migrate temporarily to the oil-rich Persian Gulf states and Singapore despite grave restrictions on many of their employment-related and other rights while employed in those countries.

Better access for workers in low income countries to labour markets in higher income countries also means better access for employers in high income countries to workers in lower income countries. In 'flexible' labour markets with weak mechanisms for enforcing labour laws and regulations, the increased supply of low-skilled migrant workers may enable some unscrupulous employers to offer jobs at inferior working conditions. In order to avoid this from happening - i.e. to prevent TMPs from allowing an almost unlimited trade-off between migrants' rights and economic gains - special safeguards are necessary that go beyond the immigration and employment law enforcement measures discussed in section 2 .

To this end, it is first necessary to recognize that one of the primary sources of migrants' vulnerability while employed under TMPs is the requirement that they work for the employer specified on the work permit only. Tied in this way to their employers, migrants may find it difficult or impossible to escape unsatisfactory working conditions (unless they are willing and financially able to return home). The problem may be exacerbated by some employers' illegal practices of retaining migrant workers' passports and by the provision of "tied accommodation", i.e. accommodation provided by the employer to their migrant workers on the condition that - and as long as - the migrant keeps working for that employer. This may naturally result in employers gaining excessive control over migrant workers, and lead to exploitation. 
An effective protection of migrants' rights thus requires at least some portability of temporary work permits enabling migrants to change employers whenever necessary. Of course, as mentioned above, it is important to recognize that immediate, complete and unlimited portability, across all occupations and sectors of the host country's labour market, would undermine the alignment of the size and composition of economic immigration with what is likely to be a sector-specific demand for migrant labour. In addition, it may also result in a substantially reduced propensity on the part of local employers to recruit migrant workers. This is mainly because employers may be reluctant to recruit migrant workers who are free to leave the employer who recruited them before at least part of the employer's recruitment costs have been recovered.

A more realistic policy objective would be to facilitate the portability of temporary work permits within a defined job category and after a certain period of time. The decision on the duration of the time period after which permits are to become portable requires a realistic assessment of the time needed for employers to cover at least part of their basic migrant worker recruitment costs. Arguably, this period is unlikely to exceed six months. It is important to note in this context that it may not be desirable for employers to be given a guarantee that they will be given the opportunity to recover all their migrant worker recruitment costs. The reason is that such a policy could significantly reduce employers' risks associated with hiring migrant workers relative to those associated with recruiting local workers (who may leave the employer anytime, i.e. also before the employers' investment in the workers have been recovered). This could, in turn, encourage employers to recruit migrant workers over local workers.

In addition to making work permits portable within certain occupations/sectors and after a certain period of time, important supplementary policies would need to include making it a criminal offence for employers to retain their workers' passports, and providing information to migrant workers about affordable housing opportunities, if they exist, other than those offered by the employer.

\section{Maximising the developmental impacts of migration in countries of origin}

There is now a substantial and growing number of studies that analyse the impacts of international labour migration on economic development in migrants' countries of origin. $^{44}$ The major areas of impacts discussed in the literature pertain to: the transfer of remittances; production and labour market effects arising from the departure and/or return of workers (including issues related to the "brain drain"); and fiscal impacts.

A general conclusion that can be drawn from existing studies, and from the experiences of large-scale exporters of workers such as the Phillipines, Egypt and Mexico is that, on its own, sending workers abroad is highly unlikely to be an effective 'development strategy'. Furthermore, it is widely agreed that the various impacts of emigration can

\footnotetext{
${ }^{44}$ For recent reviews, see Lucas (2005), Martin (2004), Commander, Kangasniemi, and Winters (2004), the House of Commons International Development Committee (2004), Ellerman (2003), and Van Hear and Sorensen (2003).
} 
involve both costs and benefits, with the overall effects often remaining ambiguous. A recent ILO report on migrant workers in the global economy thus concluded that "migration can, in some cases, contribute positively to development where a country is already poised to develop; it cannot, however, create such conditions". ${ }^{45}$

Compared to permanent immigration programmes or illegal immigration, TMPs could impact on the effects of emigration in two major ways, namely, by increasing remittances and encouraging return.

\section{Increasing remittances}

TMPs could increase remittances in three different ways. First, as discussed in section 3, by providing workers from low-income countries better access to labour markets in high income countries, TMPs could significantly raise the number of migrant workers legally admitted and employed in high income countries. This could increase the total amount of remittances received by sending countries.

Second, one may expect migrants with the intention to return, and with families in their home countries, to be more likely to remit more of their wages to countries of origin than migrants with permission and intention to reside abroad on a permanent basis. Although the empirical evidence on this issue is mixed, a recent review of the literature ${ }^{46}$ suggests that the existing evidence may be interpreted to suggest that remittances initially increase but eventually decrease with a migrant's duration of stay in the host country, reflecting the counteracting forces of wage increases (which increase remittances) and increased detachment from the home country (lowering remittances) over time.

Third, if effectively enforced, TMPs may facilitate a more effective protection of migrants' wages and employment conditions than would be the case if migrants were employed illegally. Higher wages could lead to more remittances.

It is important to emphasise that a higher volume of remittances does not necessarily lead to greater development. In fact, the effects of remittances, both in theory and practice, are generally held to be mixed. ${ }^{47}$ The theoretical benefits of remittances can include, among other things: an ease in foreign exchange constraints and improvements in the balance of payments; the potential creation of savings and investment capital, plus the multiplier effects from additional spending; the benefits from improved access to education and health care funded by remittances; and the creation of social capital which may contribute to economic development. On the other hand, remittances that are predominantly spent on conspicuous consumption could increase inflation. It has also been suggested that remittances could harm economic growth by inducing a diminished work effort and labour supply of recipients of the remittances. ${ }^{48}$

\footnotetext{
${ }^{45}$ ILO (2004), p.30.

${ }^{46}$ Lucas (2004)

${ }^{47}$ For a review of the potential benefits and costs of remittances, see, for example, Russell (1986).

${ }^{48}$ Chami, Fullenkamp and Jahja (2003).
} 
One of the few firm conclusions that can be drawn from the literature on remittances is that their impacts (including potential positive impacts on development) critically depend on their use in sending countries. ${ }^{49}$ It can then be argued that, compared to illegal immigration, TMPs could help encourage a productive use of remittances by offering migrants access to legal channels of transferring money to their home countries. Although sending remittances through legal rather than informal channels may not necessarily affect the overall volume of remittances ${ }^{50}$, money sent through legal channels may have a higher probability of being saved in formal bank accounts and thus potentially lead to productive investments by others in migrants' countries of origin.

\section{Benefits from migrants' return}

TMPs encourage the return of migrants after their work permits have expired. In theory, the return of migrant workers to their home countries could benefit economic development in a number of ways. First, in the case of skilled and highly skilled workers, it could help reverse some of the potential adverse effects that are associated with the departure of skilled labour - such as doctors and nurses - from sending countries with a shortage of such workers. Second, some workers may also acquire knowledge and skills abroad which may be transferred and used productively upon their return to their home countries. Third, returning migrant workers could use their savings to set up businesses and therefore create wider developmental benefits for the communities in their home countries. Again, policies unrelated to the TMP itself, such as measures that help reintegrate returning migrants and set up businesses, could make a big difference to materializing these potential benefits in practice.

The general conclusion one can draw from this brief discussion is that there is some, but certainly not clear-cut and undisputed, evidence to suggest that, compared to permanent migration programmes and illegal migration, TMPs can help maximize the developmental impact of emigration for countries of origin. What is clear, however, is that TMPs can only succeed in doing so if they are accompanied by other conducive policies in migrants' countries of origin including, for example, measures that encourage a productive use of remittances. Of course, another critical assumption in this discussion has been that migrants employed under TMPs actually do return to their home countries after their work permits have expired. The policies required to help achieve this in practice are discussed in the following section.

\section{Addressing concerns in high income countries about the permanent settlement of migrants and the diversity of their societies}

Many of the TMPs implemented in continental Europe in the 1960s and 1970s eventually led to the permanent settlement of guest workers, family reunion and the emergence of

\footnotetext{
${ }^{49}$ For a discussion about how to maximise the development impacts of remittances, see, for example, Carling (2005) and Lowell and de la Garza (2000).

${ }^{50}$ See the discussion in Pieke, Van Hear and Lindley (2005).
} 
new ethnic minorities. The outcomes of Germany's guest worker programmes are among the best-known and most frequently cited examples. Despite the official recruitment stop in 1973, a significant number of guestworkers chose to remain in Germany. Many of the migrants who remained were soon joined by their family members. As a result, instead of declining as anticipated and intended, the total number of resident foreigners in Germany actually increased from 4 million in 1973 to 4.4 million in $1985 .^{51}$ It was clear by the late 1980s that the guest-worker programme had turned Germany into a "country of permanent immigration", although this was officially acknowledged by the German government only in the late 1990s. ${ }^{52}$

The Bracero programme in the US is another example of how a guest worker programme can lead to levels of immigration that are significantly larger than initially intended. In contrast to the German experience, however, the Bracero programme increased the number of migrants through illegal immigration (rather than family reunification) that occurred both during and especially after the termination of the programme. There is today an officially acknowledged population of almost 11 million undocumented migrants, including more than 6 million Mexicans, in the US. ${ }^{53}$ The emergence of a large pool of illegal migrant workers is widely considered to be one of the primary legacies of the Bracero Programme. ${ }^{54}$

The experiences of the Gastarbeiter and Bracero programmes - and indeed those of most guest worker programmes in liberal democracies - make clear that any TMP will always lead to pressures for permanent settlement of at least some of the migrants admitted as guest workers. These pressures may stem from a variety of sources including ${ }^{55}$ :

- unmanaged demand for migrant labour that becomes entrenched in the economy and may persist even during times of economic downturn ${ }^{56}$;

- the emergence of a migrant worker recruitment industry and migrant networks, both of which may help sustain and perpetuate migration flows - often in an illegal manner - even when the legal institutions and factors that caused the initial migration are no longer there;

- the importance of rights in liberal democracies and the resulting pressure from the judiciary and civil society to grant migrants who have been working and residing in the country for a certain number of years the right to permanent residence; and

- migrant workers' agency, i.e. migrants' ability - as people rather than simple units of labour - to make independent and rational decisions and change their plans if necessary based on new information and circumstances.

\footnotetext{
${ }^{51}$ High birthrates were another important factor contributing to the increase in the number of foreigners in Germany during that period.

${ }_{52}^{52}$ For a discussion of similar developments in other European countries, see Castles (1986).

${ }^{53}$ Passel (2005).

${ }^{54}$ See the discussion in Martin and Teitelbaum (2001).

${ }^{55}$ For a more detailed discussion of the factors that shape migration policymaking, see Castles (2004).

${ }^{56}$ For example, the financial crisis in South East Asia in the mid 1990s did not, as widely expected, lead to a significant decline in the demand for migrant labour. In Thailand, for example, the shrimp industry continued to require Burmese workers as many Thai workers - even when unemployed during an economic downturn - were not available to do this work any longer.
} 
Given these pressures, it needs to be acknowledged that TMPs will never achieve 'perfect rotation' of migrants and thereby completely avoid the permanent settlement of migrants. This does not mean, however, that TMPs will inevitably lead to the permanent settlement of the majority of migrants admitted on a temporary basis. ${ }^{57}$ But in order to avoid the settlement of a significant number of workers with temporary work permits, the host country needs to pursue active policies aimed at managing the various pressures described above.

Two policies already discussed in this paper are measures required to manage the demand for migrant labour, and the strict enforcement of immigration and employment laws. The remainder of this section discusses an additional mixture of incentives and enforcement measures that may facilitate return. It concludes with a brief discussion of whether the facilitation of the limited and conditional transfer of some migrants employed on temporary permits into a permanent immigration programme can be compatible with the basic objectives of a TMP.

\section{Measures to facilitate return}

A number of policies are needed to facilitate and maintain the general expectation of temporariness of migrants' stay under a TMP. First, policies need to be in place that prevent a situation in which a foreign worker decides to overstay a temporary work permit because his/her savings target could not be achieved within the period of validity of the work permit. This requires strict enforcement against employers and recruiters who provide foreign workers with misleading information about employment conditions and living costs in the receiving country, and against employers who engage in 'contract substitution'. This describes the illegal practice whereby, despite having signed an authorised contract prior to departure, upon arrival in the country of employment, the migrant worker is issued with a new contract specifying lower conditions of work and/or pay. 58

A related second policy is to issue temporary work permits for a period of time that allows migrant workers - especially those employed in occupations that do not pay high wages - to generate the net financial gains necessary to make migration financially worthwhile for them. For example, the UK's current SBS schemes issue one-year work permits for employing migrants in low-wage occupations in hospitality and food processing sectors. It is highly questionable whether it is realistic to expect that it makes any financial sense for Bangladeshi workers - who have been the largest group of recipients of SBS permits - to migrate and work in a low-wage job in the UK for one year only.

Third, migrant workers with a valid work permit need to be given the right and opportunity to travel freely - or at the least without excessive restrictions - between the

\footnotetext{
${ }^{57}$ It is frequently forgotten, for example, that the majority of Germany's guest workers did return to their home countries.

${ }^{58}$ ILO (1999)
} 
sending and receiving countries. This will help migrants maintain networks in the home country, which in turn would increase the probability of their return.

Fourth, financial return incentives could include the transfer of migrant workers' social security payments to the workers' countries of origin. A recent study ${ }^{59}$ of the portability of pension and health care benefits for international migrants concludes that that only 20 percent of migrants worldwide currently work in host countries where full portability of pensions benefits (but not necessarily of healthcare benefits) to their home countries is assured. It suggests that the lack of portability of long-term social security benefits in many countries may hinder return migration and likely contributes to the informal employment of migrants in host countries.

Host countries could also create special savings accounts offering migrant workers the opportunity to save part of their wages at special high interest rates under the condition that the savings will only be released to migrant workers upon their return to their home countries. Such financial return incentives have been tried before, with mixed success. The most infamous example is the Mexican Bracero programme that required a portion of migrants' earnings to be deducted for retirement in Mexico. The policy ultimately failed as migrants never received the money and their claims for deferred wages have been under investigation for decades.

A sixth policy option for facilitating return is to require employers to make a financial security bond for each migrant worker employed, with the bond being confiscated if the worker does not leave the country after his or her work permit has expired. This system is currently in place in Singapore where employers of non-Malaysian workers need to make security bonds of $S \$ 5,000$ per worker employed. Of course, this measure can only work if it is possible to ascertain whether a migrant has actually left the country. It also raises a number of civil liberty concerns based on which security bonds have often been opposed in liberal democracies. It is interesting to note, however, that both the government and major opposition party in the UK have recently proposed the imposition of security bonds as a way of controlling illegal immigration and illegal working of migrants. ${ }^{60}$

Finally, there is also a need for clear and effective procedures for punishing employers who employ migrant workers without valid work permits (see the discussion in section 2), as well as for removing migrant workers who illegally overstay their temporary work visas. The latter is likely to require efforts to solicit the cooperation and help from sending countries. The sending countries could, for example, take measures to regulate their migrant worker recruitment industries and to assist with the return of migrant workers who have been apprehended and deported by authorities of the migrant receiving country. Of course, receiving countries could only solicit such support from sending countries if the receiving countries operate liberal and orderly managed TMPs for migrant workers from those countries in the first place.

\footnotetext{
${ }^{59}$ Holzmann, Koettl and Chernetsky (2005)

${ }^{60} \mathrm{See}$, for example, UK Home Office (2005a)
} 
Are temporary migration programmes compatible with the limited transfer of selected migrants into a permanent immigration programme?

The definition of a TMP given in the introduction to this paper suggests that residence and employment on the basis of a temporary work permit alone does not create an entitlement to stay permanently in the host country. This means that a TMP can never give an upfront guarantee, or even raise the expectation, that a migrant admitted under the programme will eventually and independently acquire the right to permanent residence in the host country. This does not preclude the possibility, however, that the host country facilitates a strictly limited and regulated transfer of migrants employed on TMPs into permanent residence based on a set of clear rules and criteria.

This could be achieved, for example, through a 'points system' that regulates the granting of permanent residence to both applicants from abroad and migrants already resident and employed on temporary permits in the host country. Under such a system, additional points could be awarded to applicants with current or past work experience in the host country. Canada is an example of where such a system is currently in place. ${ }^{61}$

To be eligible for the acquisition of permanent residence under Canada's points system, applicants must: (i) meet certain minimum work experience requirements, (ii) prove that they have the funds required for settlement; and (iii) earn enough points in six selection factors to meet the "pass mark". The six selection factors are education, language skills, experience, age, arranged employment in Canada and "adaptability" (including previous work experience and/or study in Canada). Importantly, applications are received from both non-residents and resident migrants currently employed on temporary work permits.

It is sometimes suggested that even the possibility of a strictly regulated and conditional transfer of migrants on temporary permits into a permanent migration programme would undermine the basic idea of a TMP. This is because it would, so the argument goes, create in migrants an expectation of permanence when a TMP should in fact be trying to achieve the opposite, i.e. create an expectation of temporariness of stay.

While acknowledging that this may be a potential danger in theory, one may argue that it need not necessarily be the case in practice. A well-designed mechanism for limited and conditional upgrading into permanent residence is unlikely to raise expectations about permanency as long as two conditions are met: (i) the rules and criteria for upgrading from temporary to permanent residence and employment status need to be transparent and accessible to migrants before migrating and taking up employment on a temporary work permit ${ }^{62}$; and (ii) the conditions that migrants already employed under a TMP need

\footnotetext{
${ }^{61}$ For information about the Canadian points system, see http://www.cic.gc.ca/english/skilled/qual-1.html .

${ }^{62}$ In addition, migrants need to be prevented from expecting that the rules for upgrading will change in their favour. This may only be a minor complication in practice as the changes made to, for example, points systems are usually incremental (e.g. change the number of points given for certain skills in response to changes in the host country's labour market) rather than so radical as to affect the eligibility of a large number of migrants in a short period of time.
} 
to fulfill in order to gain permanent residence need to be at least as strict as those imposed on non-resident applicants for permanent residence.

In addition to avoiding adverse effects on a TMP's objective of facilitating return, the possibility of a regulated and conditional transfer of migrants employed on TMPs into permanent residence may generate distinct benefits for the host country. For example, compared to a non-resident worker applying for permanent residence, an already resident migrant who fulfills all the criteria for admission to the permanent labour immigration programme would already have some experience of working and living in the host country, making him/her likely to more quickly and successfully integrate into the host country's society.

One could also argue that it is simply necessary to accept that there will always be some migrants who join TMPs with the genuine intention to leave after their temporary work permits expire but who change their intentions after working in the host country for a while. The possibility of conditional upgrading into permanent residence based on clear rules and criteria would give some of such migrants the possibility to work toward acquiring the skills necessary to fulfill these conditions for transfer into permanent residence status. Of course, this would only be possible for migrants whose qualifications at the time of admission into the host country are such that they have a realistic hope of meeting the criteria for permanent residency by the time their temporary work permits expire. The benefit for the host country may be to help relieve pressures for illegal overstaying.

\section{Conclusion}

This paper has argued that, in theory, temporary migration programmes (TMPs) can generate significant net-benefits for receiving countries, migrants and their countries of origin. TMPs can help host countries to manage the demand for migrant labour; help migrants to gain better legal access to the labour markets of high-income countries; and help sending countries in their efforts to maximize the developmental benefits from emigration.

To achieve these potential net-benefits in practice, however, will almost certainly require a high degree of government involvement and intervention in the labour market. Some of the major policies required and discussed in this paper include:

- the strict enforcement of immigration and employment laws, especially against employers who illegally employ migrants and/or violate minimum wage and employment regulations

- the regulation of the cost at which migrants are made available to employers through, for example, the charging of monthly work permit fees for each migrant employed

- the implementation of effective labour market tests, i.e. of mechanisms that incentivise employers to recruit migrant workers only after all reasonable efforts have been made to recruit local workers 
- the regulation or at least the monitoring of the migrant recruitment industry with an eye to monitoring/controlling migrants' costs of migration

- the protection of migrants' rights by making work permits portable within certain sectors/occupations and after a certain period of time;

- mixed incentives-enforcement measures to facilitate the return home of migrants whose temporary work permits have expired

It has also been argued that it may be mistaken to a priori discard, as it is frequently done in discussions about TMPs, the possibility of enabling a small minority of migrants employed on temporary permits to upgrade into permanent residence status based on a clear set of rules and criteria (e.g. through a points system). As long as those criteria are transparent and at least as strict as those used to regulate permanent labour immigration of non-resident foreign workers, such a policy need not necessarily create, as is commonly suggested, an expectation of permanence in migrants who join the TMP.

It is important to emphasise that there is no evidence yet that it will be possible to effectively implement all of the policies above in practice. This means that the feasibility of TMPs remains contested. Any attempt to re-introduce new and expanded TMPs would therefore need to start with experimental pilot programmes that test some of the policy measures required to make such programmes work. Experimentation with new TMPs has already begun in some countries. ${ }^{63}$

Furthermore, to help avoid unanticipated consequences, the design and implementation of TMPs will need to set realistic policy objectives and have a clear understanding of what TMPs can and cannot achieve. It needs to be recognized, for example, that TMPs will not suffice as the only tool for managing labour immigration. They are also unlikely to be a means of completely preventing the permanent settlement of all migrant workers admitted under such programmes. Furthermore, unless accompanied by effective enforcement of immigration and employment laws, TMPs are unlikely to be an efficient way of reducing illegal immigration.

Finally, even if they turn out to be feasible, it is important to recognize that the introduction of new and expanded TMPs raises important ethical questions. As discussed in this paper, on its own, residence and employment on the basis of a temporary work permit does not create an entitlement to permanent residence in the host country. Furthermore, to make TMPs benefit host countries, it will be necessary to restrict migrants' freedom of movement to certain sectors in the host country's labour market.

Can these restrictions of migrants' rights, and some of the other policies necessary to make TMPs work, be justified - and advocated - as desirable labour immigration policy measures in a liberal democracy? At the theoretical level, the answer primarily depends on one's preferred ethical framework for evaluating public policies. ${ }^{64}$ At a more practical level, it could simply be argued that, at least as far as managing the international

\footnotetext{
${ }^{63}$ See, for example, the SBS programme in the UK.

${ }^{64}$ For a discussion of the ethics of labour immigration policy, see Ruhs (2005b) and Ruhs and Chang (2004)
} 
migration of low-skilled workers is concerned, TMPs beat the currently available alternatives of illegal immigration or permanent immigration programmes. Despite its widespread occurrence in many countries, the former is widely dismissed as an unsustainable labour immigration 'policy' in the long term. At the same time, permanent immigration is unlikely to anytime soon become a politically realistic policy for recruiting significant numbers of low-skilled workers in high income countries. The current permanent immigration programmes benefit a few skilled migrant workers, but leave much larger numbers of low-skilled workers in low income countries excluded from the global labour market. 


\section{REFERENCES}

Carling, J. (2005) 'Policy options for increasing the benefits of remittances', COMPAS Working Paper 8, Centre on Migration, Policy and Society (COMPAS), Oxford University

Castles, S. (2004) 'Why Migration Policies Fail', Ethnic and Racial Studies 27 (2): 205227

Castles, S. (1986) 'The Guest-Worker in Western Europe - an Obituary', International Migration Review 20(4): 764-778.

Chami, R., C. Fullenkamp, and S. Jahja (2003), 'Are Immigrant Remittance Flows a Source of Capital for Development?', IMF Working Paper WP/03/189, IMF, Washington, DC

Cholewinski, R. (2005) The legal status of migrants admitted for employment, Council of Europe Publishing, Strasbourg

Commander, S., Kangasniemi, M. and L.A. Winters (2004) 'The brain drain: curse or boon? A survey of the literature', in R. Baldwin and L.A. Winters (eds.) Challenges to Globalization, NBER and University of Chicago Press, Cambridge, MA

Cornelius, W. (2004) 'Controlling Unwanted Immigration: Lessons from the United States, 1993-2004', downloadable at www.compas.ox.ac.uk

DeVoretz, D. (2002) 'A Model of Optimal Canadian Temporary Immigration', Research on Immigration and Integration in the Metropolis, Commentary Series 02-04, RIIM, Vancouver

Ellerman, D. (2003), 'Policy Research on Migration and Development', World Bank Policy Research Working Paper 3117, August 2003, World Bank, Washington, DC.

Hanson, G. and A. Spilimbergo (2001) 'Political Economy, Sectoral Shocks, and Border Enforcement', Canadian Journal of Economics 34(3): 612-638.

Holzmann, R., Koettl, J. and T. Chernetsky (2005) 'Portability regimes pf pension and healthcare benefits for international migrants: An analysis of issues and good practices', A paper prepared for the Global Commission on International Migration, May 23, 2005

House of Commons International Development Committee (2004), Migration and Development: How to make migration work for poverty reduction, Sixth Report of Session 2003-04, Volume I, House of Commons, London

International Labour Organisation (2004) Towards a fair deal for migrant workers in the global economy, Report prepared for the International Labour Conference 2004, Geneva 
International Labour Organisation (1999) Migrant Workers, ILO, Geneva

International Organisation for Migration (2005) World Migration 2005, IOM, Geneva

Lewis, R. (2005) 'Immigration, skill-mix, and the choice of technique', Working Paper No. 05-8, Federal Reserve Bank of Philadelphia, Philadelphia

Lewis, R. (2004) 'How did the Miami labour market absorb the Mariel immigrants?', Working Paper No. 04-3, Federal Reserve Bank of Philadelphia, Philadelphia

Lowell, L. (2005) 'Immigration as a labour market strategy in the United States', in Niessen, J. and Y. Schibel (eds.) Immigration as a labour market strategy - European and North American Perspectives, Migration Policy Group, Brussels

Lowell, L. and de la Garza, R. (2000) The Developmental Role of Remittances in US Latino Communities and in Latin American Countries, Inter-American Dialogue, Washington DC

Lucas, R. (2005) International Migration And Economic Development: Lessons from Low-income Countries, Edward Elgar

Lucas, R. (2004) 'International migration to the high income countries: Some consequences for economic development in the sending countries', Paper prepared for the Annual World Bank Conference on Development Economics - Europe, Brussels, May 10-11, 2004.

Martin, P. (2004), 'Migration and development: toward sustainable solutions', Discussion Paper 152, International Institute for Labour Studies, International Labour Organisation, Geneva.

Martin, P. (2003) Managing Labour Migration: Temporary Worker programs for the $21^{\text {st }}$ Century, Special lecture on migration, International Institute for Labour Studies, International Labour Organisation (ILO), Geneva

Martin, P. and M. Teitelbaum (2001) 'The Mirage of Mexican Guest Workers', Foreign Affairs 80(6): 117-131

Martin, P. and M. Miller (2000) 'Employer Sanctions; French, German and US Experiences', International Migration Papers 36, International Labour Office (ILO), Geneva.

Martin, P. and A. Olmstead (1985) 'The Agricultural Mechanization Controversy', Science 227: 601406.

Organisation for Economic Co-operation and Development (2004) Migration for Employment. Bilateral Agreements at a Crossroads, OECD, Paris 
Passel, J. (2005) Estimates of the size and characteristics of the undocumented population, Report of the Pew Hispanic Center, March 21, 2005.

Pieke, F., Van Hear, N. and A. Lindley (2005) Synthesis Study of Informal Remittance Systems in Africa, Caribbean and Pacific (ACP) Countries, a report prepared for the Department of International Development (DFID), UK

Ruhs, M. (2005a) Managing the immigration and employment of non-EU nationals in Ireland, Studies in Public Policy: 19, The Policy Institute, Trinity College Dublin

Ruhs, M. (2005b), 'Designing viable and ethical labour immigration policies', chapter 10 in World Migration 2005, International Organisation for Migration (IOM), Geneva.

Ruhs, M. and H-J. Chang (2004) 'The Ethics of Labor Immigration Policy', International Organization 58(1): 69-102.

Ruhs, M. (2003) 'Temporary Foreign Worker Programmes: Policies, Adverse Consequences and the Need to Make Them Work', Perspectives on Labour Migration 6, International Migration Branch, International Labour Organisation (ILO), Geneva.

Russell, S. (1986) 'Remittances from International Migration: A Review in Perspective', World Development, 14 (6): 677-96.

Schiff, M. (2004) 'When Migrants Overstay Their Legal Welcome: A Proposed Solution to the Guest-Worker Program', IZA Discussion Paper 141, Institute for the Study of Labour, Bonn

UK Home Office (2005a) Selective Admission: Making Migration Work for Britain, available at www.homeoffice.gov.uk

UK Home Office (2005b) Sector-Based Scheme Review, available at www.homeoffice.gov.uk

UK Home Office (2003) Control of Immigration: Statistics United Kingdom 2002, TSO, London.

United Nations Conference on Trade and Development (2001) World Investment Report 2001, UNCTAD, Geneva.

United Nations Population Division(2002) International Migration Report 2002 (ST/ESA/SER.A/220), UNPOP, New York

Van Hear, N. and N. Sorensen, eds. (2003) The Migration-Development Nexus, IOM, Geneva 
Weinstein, E. (2002) 'Migration for the Benefit of All', International Labour Review 141(3): 225-252. 